\title{
Pengaruh Karakteristik Perusahaan, Karakteristik Obligasi, Reputasi Auditor Terhadap Peringkat Obligasi
}

\author{
Rovinson Wijaya \\ Universitas Katolik Soegijapranata \\ rovinsonwijaya97@gmail.com
}

\begin{abstract}
This study aims to examine the factors affecting the rating of obligations provided by PEFINDO on public companies listed on the Indonesia Stock Exchange with observation period 2012-2016. Independent variables in this study are company characteristics consisting of retained earnings and profitability, obligation characteristics consisting of obligation guarantee and obligation maturity, and auditor reputation. The sample was taken by using purposive technique and obtained 203 public companies listed in Indonesia Stock Exchange. Regression results show that the retained earnings, profitability, and reputation of the auditor are positively influenced by the obligation rating, while the obligation guarantee and obligation maturity have no effect on the bond rating.
\end{abstract}

Key words: Rating of obligations, company characteristics, obligation characteristics, auditor reputation.

\begin{abstract}
Abstrak
Penelitian ini bertujuan untuk menguji faktor-faktor yang mempengaruhi peringkat obligasi yang diberikan PEFINDO pada perusahaan publik yang terdaftar pada Bursa Efek Indonesia dengan periode pengamatan 2012 - 2016. Variabel independen dalam penelitian ini berupa karakteristik perusahaan yang terdiri dari laba ditahan dan profitabilitas, karakteristik obligasi yang terdiri dari jaminan obligasi dan umur obligasi, serta reputasi auditor. Sampel diambil dengan menggunakan tehnik purposive dan didapat 203 perusahaan publik yang terdaftar di Bursa Efek Indonesia. Hasil regresi menunjukkan bahwa besar laba ditahan, profitabilitas, dan reputasi auditor bepengaruh positif terhadap peringkat obligasi, sedangkan jaminan obligasi dan umur obligasi tidak berpengaruh terhadap peringkat obligasi.
\end{abstract}

Kata kunci: Peringkat obligasi, karakteristik perusahaan, karakteristik obligasi, reputasi auditor.

\section{PENDAHULUAN}

Seiring dengan pertumbuhan perekonomian yang ada pada Indonesia, pasar modal merupakan salah satu pilihan dari kalangan masyarakat untuk dijadikan sebagai ladang investasi dengan maksud untuk mendapatkan manfaat atau keuntungan di masa yang akan datang. Pasar modal di Indonesia memiliki berbagai macam pilihan sekuritas, pemilik modal diberi kesempatan untuk memilih diantara berbagai sekuritas tersebut. Salah satu sekuritas yang diperdagangkan di pasar modal adalah obligasi. Menurut Veronica (2013) Obligasi itu 
sendiri merupakan salah satu sumber pendanaan perusahaan ataupun pemerintah yang berupa surat utang jangka panjang yang diterbitkan dengan nilai tertentu dan waktu jatuh tempo tertentu. Investasi obligasi merupakan salah satu investasi yang banyak diminati oleh pemodal. Hal ini dikarenakan obligasi memilki pendapatan yang bersifat tetap yang diperoleh dari bunga yang akan diterima secara periodik dan pokok obligasi pada saat jatuh tempo (Rusfika dan Wahidahwati, 2015). Setiap Obligasi yang beredar pasti akan diberi peringkat oleh agen pemeringkat obligasi. Menurut Andry (2005) Agen pemeringkat obligasi adalah lembaga independen yang memberi informasi pemeringkatan skala risiko utang, salah satu diantaranya adalah sekuritas obligasi, sebagai petunjuk seberapa aman suatu obligasi bagi investor.

Keamanan ini ditunjukkan oleh kemampuannya dalam membayar bunga dan melunasi pokok pinjaman. Pemodal bisa menggunakan jasa agen pemeringkat obligasi tersebut untuk mendapatkan informasi mengenai peringkat obligasi. Di Indonesia terdapat dua lembaga pemeringkat sekuritas utang, yaitu PT PEFINDO (Pemeringkat Efek Indonesia) dan PT Kasnic Credit Rating Indonesia. Peringkat obligasi dalam perannya juga memberikan manfaat untuk kedua belah pihak dan untuk masing-masing pihak juga, baik dari segi perusahaan dan dari segi investor. Manfaat untuk kedua belah pihak yaitu hasil dari peringkat obligasi ini dapat meminimalisir konflik antar perusahaan dengan investor, karena perusahaan juga ingin seluruh obligasinya terjual dan investor juga ingin memiliki penjaminan kondisi perusahaan yang sehat agar investor tidak merugi. Bagi sisi perusahaan juga mendapatkan manfaat dengan meniadakan biaya penjaminan untuk para investor, dan bagi investor juga mendapatkan manfaat dengan meniadakan biaya untuk menganalisis kondisi kesehatan sebuah perusahaan.

Di Indonesia sendiri tedapat fenomena dengan salah satu emiten yang mengalami gagal bayar (default). PT Trikomsel Oke Tbk (TRIO) mengalami gagal bayar (default) dari tanggal jatuh tempo pada 11 November 2015 senilai Rp 40,2 Miliar, dan pada 5 Desember 2015 senilai Rp 52,26 Miliar, dan dari Utang-utang TRIO ini memiliki potensi cross default, dan dari ketidakmampuan TRIO ini dalam membayar bunga obligasi, PT Pefindo menurunkan peringkat TRIO dari id CCC menjadi id SD (selective default). Peringkat ini menandakan obligor gagal membayar satu atau lebih kewajiban finansialnya yang mengalami jatuh tempo (Gunawan, 2015). Dalam kasus yang terjadi dari contoh diatas sangat jelas bahwa investor sangat merugi karena segala investasi yang menjanjikan nilai nominal yang tinggi pasti juga memiliki risiko yang tinggi pula, selain itu mereka benar-benar tidak dapat melakukan apapun selain menunggu perusahaan untuk melunasi hutangnya, terlebih lagi investor hanya dapat melihat pengukuran suatu perusahaan berdasarkan peringkat obligasi saja, sehingga investor tidak mengetahui secara pasti mengenai faktor-faktor apa saja yang bisa mempengaruhi hasil peringkat obligasi. Peringkat obligasi yang diberikan PT. Pefindo juga bias, hal ini disebabkan karena agen Moody's dan $S$ dan $P$ 's tidak melakukan monitor terhadap kinerja perusahaan setiap harinya, dengan demikian PT. PEFINDO hanya bisa memberikan peringkat setelah terjadinya suatu peristiwa yang dapat menyebabkan perubahan peringkat (Chan et al. 1999 dalam Sunarjanto dan Tulasi, 2013). Dari penjelasan fenomena diatas, maka penelitian ini bertujuan untuk mengidentifikasi faktor-faktor yang mempengaruhi peringkat obligasi.

\section{TINJAUAN LITERATUR DAN PERUMUSAN HIPOTESIS}

\section{Peringkat Obligasi}

Seorang pemodal yang tertarik berinvestasi obligasi tentunya harus melihat rating obligasi sebagai acuan mereka. Rating atau peringkat, merupakan sebuah pernyataan mengenai kondisi pengutang dan kemungkinan apa saja yang bisa dan akan dilakukan berkaitan dengan utang yang dimiliki, sehingga dapat disimpulkan bahwa rating mencoba mengukur default risk, yaitu peluang perusahaan akan mengalami keadaan tidak mampu melunasi kewajiban keuangannya Adrian (2011). Peringkat obligasi perusahaan 
diharapkan dapat memberikan petunjuk bagi investor tentang kualitas investasi obligasi yang mereka minati.

\section{Saldo Laba}

Octavia (2014) menjelaskan secara umum bahwa saldo laba (laba ditahan) merupakan laba bersih yang tidak dibayarkan sebagai dividen tetapi diakumulasikan selama masa usaha perusahaan dan dilaporkan pada bagian kekayaan bersih atau ekuitas di dalam laporan posisi keuangan. Sedangkan Fahmi (2011) dalam Estiyanti dan Yasa (2012) menyatakan bahwa laba ditahan (retained earning) merupakan akumulasi penghasilan dari perusahaan setelah dikurangkan dengan dividen.

\section{Profitabilitas}

R. Agus Sartono (2002) dalam Adrian (2011) menyebutkan bahwa rasio profitabilitas merupakan salah satu indikator keberhasilan perusahaan untuk dapat menghasilkan laba yang memiliki hubungan dengan penjualan, total aset maupun modal sendiri. Profitabilitas bisa diukur menggunakan ROA, Sutrisno (2009) dalam Rusfika dan Wahidahwati (2015) juga membahas bahwa ROA adalah kemampuan perusahaan dengan mendapatkan laba dengan semua aktiva/aset yang perusahaan miliki.

\section{Jaminan Obligasi}

Obligasi yang terjamin pastinya menjadi prioritas utama bagi para investor untuk memperkecil risiko gagal bayar (default) dari perusahaan tersebut. Menurut Andry (2005) Tingkat risiko yang ada dalam sebuah obligasi dipengaruhi oleh jaminan obligasi. Berdasarkan jaminan tersebut, obligasi dibedakan atas obligasi yang dijamin dan tidak dijamin.

\section{Umur Obligasi}

Umur obligasi (maturity) merupakan tanggal dimana pemilik obligasi akan menerima pembayaran kembali sebesar nilai pokok atau nilai obligasi dari pemilik. Periode jatuh tempo dari obligasi sangatlah bervariasi, mulai dari 365 hari sampai dengan diatas 5 tahun. Estiyanti dan Yasa (2012) mengatakan bahwa umur obligasi adalah rentang waktu sejak dimunculkannya obligasi sampai dengan tanggal jatuh tempo dari obligasi.

\section{Reputasi Auditor}

Audit adalah proses sistematis yang secara objektif mendapatkan dan mengevaluasi bukti-bukti yang berhubungan pada pernyataan tentang tindakan atau peristiwa ekonomi guna menilai tingkat kesesuaian diantara pernyataan tersebut dan syarat-syarat yang sudah ditetapkan dan mengkomukasikan hasilnya kepada pihak yang berkepentingan (Gunawijaya, 2015). Tugas auditor adalah menyatakan pendapatnya yang berpijak pada audit yang dilakukan berlandaskan standar audit serta temuan-temuannya. IAI (2001) dalam Sugiarto (2012) memaparkan "Laporan auditor harus mengandung suatu pernyataan pendapat mengenai laporan keuangan secara menyeluruh atau suatu asersi bahwa pernyataan demikian tidak bisa diberikan.

\section{Saldo Laba Dan Peringkat Obligasi}

Saldo laba merupakan akumulasi dari laba dari tahun-tahun sebelumnya setelah memperhitungkan dividen dan berbagai penyesuaian terhadap laba-rugi periodik. Saldo laba merupakan sumber pendanaan internal yang dapat dimanfaatkan perusahaan dalam membiayai berbagai proyek investasi dan membayar kewajiban jangka pendek maupun jangka panjang. Saldo laba yang dimiliki perusahaan memberi gambaran kepada investor 
tentang kemampuan perusahaan untuk bertahan dalam situasi yang sulit. Saldo laba dapat memiliki saldo negatif apabila perusahaan mengalami kerugian dalam jumlah yang sangat besar (Octavia, 2014).

Investor membutuhkan informasi saldo laba untuk menilai apakah investasi mereka dalam saham perusahaan menjanjikan return yang memadai. Sementara bagi kreditor, informasi tentang besaran saldo laba memberi jaminan tentang kemampuan perusahaan melunasi kewajiban-kewajiban mereka. Lebih jauh lagi, saldo laba yang tinggi memberi sinyal bagi kreditor tentang kemampuan perusahaan melunasi utang obligasi dan mempengaruhi lembaga pemeringkat obligasi dalam memberi peringkat obligasi. Dengan demikian, semakin tinggi saldo laba maka semakin besar pula kemungkinannya perusahaan mendapat peringkat obligasi yang baik. Hubungan saldo laba dan peringkat obligasi dinyatakan dalam hipotesis berikut:

\section{H1 : Laba ditahan berpengaruh positif terhadap peringkat obligasi}

\section{Profitabilitas Dan Peringkat Obligasi}

Mark et al. (2001) menyatakan bahwa rasio profitabilitas memberi indikasi tentang pertumbuhan laba perusahaan di masa datang. Perusahaan yang memiliki rasio profitabilitas yang rendah diprediksi akan memiliki kesulitan dalam membiayai proyekproyek investasi sehingga menghambat pertumbuhan perusahaan. Sebaliknya, perusahaan yang memiliki rasio profitabilitas yang tinggi tidak akan mengalami kesulitan yang berarti dalam membiayai aktivitas bisnis perusahaan di masa mendatang. Profitabilitas yang tinggi menunjukkan kemampuan perusahaan dalam mendorong angka penjualan melalui penjualan produk yang berkualitas atau efisiensi biaya sehingga dapat mengalahkan para pesaingnya. Kondisi ini meningkatkan kepercayaan krediotr dan investor terhadap kemampuan perusahaan melunasi semua tagihan jangka pendek atau jangkan panjang.

Perusahaan yang memiliki profitabilitas yang tinggi memiliki kemampuan lebih dibanding perusahaan lain yang kurang profitable dalam menarik sumber pendanaan dari luar melalui penerbitan obligasi. Keleluasaan dalam mendapatkan sumber pendanaan eksternal memberi kesempatan bagi perusahaan untuk mengeksploitasi berbagai kesempatan yang ada di pasar. Dengan mempertimbangkan kemampuan perusahaan dalam mengelola sumber daya yang dimiliki sehingga selalu berhasil membukukan laba, kreditor memiliki kepercayaan yang tinggi terhadap kemampuan perusahaan membayar utang dan bunga obligasi. Sementara bagi lembaga pemeringkat obligasi, kemampuan perusahaan melunasi utang dan bunga obligasi mendorong mereka untuk memberi peringkat obligasi yang tinggi. Berdasarkan pemikiran ini, hubungan antara profitabilitas dan peringkat obligasi dapat dinyatakan dalam hipotesis berikut :

\section{H2 : Profitabilitas berpengaruh positif terhadap peringkat obligasi}

\section{Jaminan Obligasi Dan Peringkat Obligasi}

Joseph (2002) dalam Azriya (2013) berpendapat apabila aset perusahaan dijaminkan untuk obligasi, maka rating obligasi pun akan membaik dan ini akan membuat obligasi tersebut dapat dikategorikan aman, terlebih apabila aset yang dijaminkan lebih besar maka rating obligasi akan semakin baik. Selain itu investor juga akan berpikir jika perusahaan berani menjaminkan obligasi yang mereka terbitkan, maka perusahaan dinilai bertanggung jawab atas obligasinya dengan dapat membayar kupon serta membayar nilai pokok obligasinya. Hal ini juga didukung oleh pernyataan Brister et al. (1994) dalam Magreta dan Nurmayanti (2009) bahwa investor lebih melirik perusahaan yang memberikan jaminan terhadap obligasi yang sudah mereka terbitkan dipasar karena investor mendapatkan rasa aman dari perusahaan dan terhindar dari asumsi gagal bayar (default) oleh perusahaan. 
Hal ini secara tidak langsung memberikan nilai positif bagi perusahaan akan pemeringkatan obligasi. Jadi dapat disimpulkan semakin tinggi jaminan obligasi yang diberikan perusahaan, maka akan semakin besar kemungkinannya mendapatkan peringkat obligasi yang baik dan dapat dinyatakan dalam hipotesis berikut:

\section{H3 : Jaminan obligasi berpengaruh positif terhadap peringkat obligasi}

\section{Umur Obligasi Dan Peringkat Obligasi}

Rusfika dan Wahidahwati (2015) menyatakan bahwa perusahaan yang menerbitkan obligasi dengan umur obligasi yang lebih pendek mengindikasikan kemampuan perusahaan untuk melunasinya dibandingkan dengan perusahaan yang memiliki obligasi dengan umur obligasi yang lebih panjang. Investor lebih memilih obligasi dengan umur yang lebih pendek karena merasa mendapatkan risiko yang lebih kecil. Umur obligasi yang lebih panjang cenderung memberikan rasa kekhawatiran terhadap investor akan adanya risiko gagal bayar (default) dikemudian harinya dan hutang jangka pendek biasanya memiliki jumlah yang lebih kecil dibanding jumlah dari hutang jangka panjang (Widowati et al. 2013).

Dari pernyataan diatas dapat disimpulkan bahwa semakin panjang umur obligasi maka akan semakin besar risiko yang ada sehingga semakin rendah peringkat obligasi yang akan diberikan dan semakin pendek umur obligasi maka semakin besar kemungkinannya perusahaan mendapatkan peringkat investment grade. Dengan demikian, hubungan antara umur dan peringkat obligasi dapat dinyatakan sebagai berikut:

\section{H4 : Umur obligasi berpengaruh negatif terhadap peringkat obligasi}

\section{Reputasi Auditor Dan Peringkat Obligasi}

Semakin tinggi reputasi auditor maka dapat diharapkan audit yang diberikan lebih berkualitas dibandingkan dengan auditor yang belum dikenal. KAP big four memiliki reputasi yang lebih baik dibanding KAP non-big four sehingga dapat diekspektasi kualitas audit yang diberikan KAP big four lebih tinggi daripada non big four. Selain itu KAP big four lebih berisiko mengalami tuntutan hukum dibanding KAP non-big four ketika melakukan kesalahan dalam mengaudit. Ini tidak terlepas dari kenyataan bahwa KAP big four memiliki kemampuan finansial yang tinggi sehingga pihak-pihak yang merasa dirugikan lebih terdorong untuk membawa masalah ini ke pengadilan daripada yang melibatkan KAP non-big four. Mereka bisa berharap jumlah kompensasi yang mereka tuntut dapat dipenuhi KAP big four. Risiko hukum yang lebih tinggi mendorong KAP big four untuk melakukan penugasan audit dengan hati-hati dan cermat.

Audit yang berkualitas meningkatkan kepercayaan investor dan kreditor terhadap keandalan laporan keuangan dalam merefleksikan kinerja perusahaan yang sesungguhnya. Laporan keuangan yang andal sangat dibutuhkan untuk menilai risiko investasi. Laporan keuangan yang andal meningkatkan kepercayaan investor tentang kemampuan perusahaan membayar utang dan bunga obligasi. Bagi lembaga pemeringkat, pemilihan KAP big four memberi sinyat positif tentang upaya perusahaan menyakinkan kreditor bahwa perusahaan telah menerapkan praktik bsinis yang sehat termasuk dalam mengendalikan risiko bisnis. Dengan menggunakan KAP big four, perusahaan berupaya menyakinkan lembaga pemeringkat bahwa default risk terkendali sehingga berharap peringkat obligasi yang mereka dapatkan menjadi lebih baik. Dengan demikian, hubungan antara reputasi auditor dan peringkat obligasi dinyatakan sebagai berikut:

\section{H5 : Reputasi auditor berpengaruh positif terhadap peringkat obligasi}




\section{METODA PENELITIAN}

\section{Populasi dan Sampel}

Populasi merupakan keseluruhan objek yang memenuhi syarat-syarat tertentu dan berkaitan dengan masalah yang diteliti Adrian (2011). Populasi yang akan diamati dalam penelitian ini adalah perusahaan yang terdaftar di BEI dan yang menerbitkan obligasi dan terdaftar dalam peringkat obligasi yang dikeluarkan oleh PT. PEFINDO selama tahun pengamatan yaitu dari tahun 2012-2016. Pemilihan sampel dilakukan dengan Teknik purposive sampling dengan kriteria: 1) Perusahaan publik yang terdatar di PEFINDO tahun 2012 sampai dengan 2016. 2) Perusahaan yang obligasinya diperingkatkan oleh PEFINDO tahun 2012 sampai dengan 2016. 3) Perusahaan penerbit obligasi yang tercatat memiliki informasi yang lengkap yang berhubungan dengan penelitian. Perusahaan yang ditemukan tidak memiliki data yang dibutuhkan dalam penelitian ini akan dieliminasi dari sampel. 4) Perusahaan yang menggunakan mata uang Rupiah. Perusahaan yang ditemukan tidak menggunakan mata uang Rupiah di laporan keuangan mereka, dalam penelitian ini akan dieliminasi dari sampel.

Jenis data yang digunakan dalam penelitan ini adalah data sekunder. Data keuangan diperoleh dari laporan tahunan yang diakses dari www.idx.co.id dan peringkat obligasi diperoleh dari dan www.pefindo.com. Tabel 1 menyajikan secara detail prosedur pengambilan sampel. Selama periode penelitian, perusahaan sampel yang dapat digunakan untuk pengujian hipotesis berjumlah 203 sampe perusahaan. Beberapa perusahaan harus dieliminasi karena tidak memenui kriteria sampel yang telah dinyatakan sebelumnya. Penelitian ini hanya membatasi pada peringkat obligasi yang diterbitkan oleh PT. PEFINDO karena perusahaan ini merupakan perusahaan pemeringkat yang memiliki kredibilitas yang tinggi di Indonesia.

Tabel 1.

Prosedur Pengambilan Sampel

\begin{tabular}{|l|c|c|c|c|c|c|}
\hline $\begin{array}{l}\text { Kriteria Pengambilan } \\
\text { Sampel }\end{array}$ & $\mathbf{2 0 1 2}$ & $\mathbf{2 0 1 3}$ & $\mathbf{2 0 1 4}$ & $\mathbf{2 0 1 5}$ & $\mathbf{2 0 1 6}$ & Total \\
\hline $\begin{array}{l}\text { Perusahaan publik yang } \\
\text { terdaftar di PEFINDO tahun } \\
\text { 2012-2016 }\end{array}$ & 120 & 138 & 129 & 129 & 145 & 661 \\
\hline $\begin{array}{l}\text { Obligasi perusahaan tidak } \\
\text { diperingkat PEFINDO }\end{array}$ & $(68)$ & $(86)$ & $(71)$ & $(72)$ & $(85)$ & $(383)$ \\
\hline $\begin{array}{l}\text { Laporan keuangan tidak } \\
\text { tersedia dari sumber }\end{array}$ & $(14)$ & $(11)$ & $(13)$ & $(15)$ & $(17)$ & $(70)$ \\
\hline $\begin{array}{l}\text { Perusahaan menggunakan mata } \\
\text { uang asing }\end{array}$ & $(3)$ & $(0)$ & $(1)$ & $(1)$ & $(3)$ & $(8)$ \\
\hline \begin{tabular}{l} 
Total Sampel \\
\hline
\end{tabular} & 36 & 41 & 45 & 41 & 40 & 203 \\
\hline
\end{tabular}

\section{Definisi Operasional dan Pengukuran Variabel}

\section{Variabel Dependen (Y)}

Variabel dependen yang digunakan dalam penelitian ini adalah peringkat obligasi (ratings obligation). Peringkat obligasi dalam penelitian ini diposisikan sebagai variabel terikat (Y). Peringkat obligasi yang dimaksud dalam penelitian ini berdasarkan peringkat yang diberikan 
oleh PT PEFINDO yang terbagi menjadi 18 kode dengan maksud peringkat yang terbaik, dari peringkat terendah (D) dengan kode 1 dan peringkat tertinggi (AAA) dengan kode 18.

\section{Variabel Independen $(\mathrm{X})$}

Berikut adalah variabel independen yang digunakan dalam penelitian ini:

\section{Laba Ditahan(X1)}

Laba ditahan didefinisikan sebagai salah satu sumber dana yang paling penting untuk membiayai pertumbuhan perusahaan. Laba ditahan dalam penelitian ini diposisikan sebagai variable bebas (X) Laba ditahan dalam penelitian ini diukur dengan membandingkan laba ditahan akhir periode satu tahun sebelum pemeringkatan obligasi dengan total assets awal periode satu tahun sebelum pemeringkatan obligasi, dan dari penjelasan tersebut ditemukan formula yang juga disebutkan dalam Octavia (2014) :

\section{Profitabilitas (X2)}

\section{Laba Ditahan $=($ Laba Ditahan Akhir Periode $) /($ Total Aset $)$}

Profitabilitas adalah kemampuan perusahaan untuk mencapai laba dalam hubungannya dengan penjualan, asset, dan modal sendiri. Variable profitabilitas dalam penelitian ini diukur dengan ROA (return on asset). Sejati (2010) menyatakan bahwa pengukuran ROA memiliki pengaruh positif terhadap pertumbuhan laba karena pengukuran ROA berdasarkan pada tingkat aset tertentu. ROA dalam penelitian ini merupakan perbandingan antara laba bersih setelah pajak dengan total aset perusahaan, dan dari penjelasan tersebut ditemukan formula yang juga disebutkan dalam Baskoro dan Wahidahwati (2014) :

\section{Jaminan Obligasi (X3)}

$$
\mathrm{ROA}=(\text { Laba Bersih Setelah Pajak }) /(\text { Total Aset })
$$

Pada dasarnya investor akan lebih merasa aman apa bila obligasi yang hendak mereka beli memiliki jaminan yang diberikan oleh perusahaan. Obligasi atas dasar jaminan dibagi menjadi obligasi dengan jaminan dan obligasi tanpa jaminan (Sulistyastuti, 2002). Variable independen ini menggunakan variable dummy. Pengukuran pada variable independen ini menggunakan skala nominal, dimana obligasi yang memiliki jaminan akan mendapatkan nilai 1, sedangkan obligasi yang tidak memiliki jaminan akan mendapatkan nilai 0, pengukuran ini mengacu pada penelitian (Rusfika dan Wahidahwati, 2015).

\section{Umur Obligasi (X4)}

Umur obligasi merupakan jarak waktu jatuh tempo dari suatu obligasi, yaitu tanggal dimana pemilik obligasi akan mendapatkan pelunasan dari nilai pokok obligasi yang mereka miliki. Penelitian ini menggunakan peringkat, perusahaan yang menerbitkan umur obligasi dalam waktu 1 tahun akan diberikan peringkat 1,2 tahun akan diberikan peringkat 2, dst. Umur obligasi yang memiliki waktu jatuh tempo hanya dalam waktu 1 tahun akan lebih mudah diprediksi dan memiliki risiko yang lebih kecil dibandingkan umur obligasi yang memiliki jangka waktu jatuh tempo diatas 5 tahun (Magreta dan Nurmayanti, 2009)

\section{Reputasi Auditor (X5)}

Reputasi auditor yang dimaksud dalam penelitian ini adalah pemberi hasil audit atas laporan keuangan untuk setiap perusahaan yaitu KAP (Kantor Akuntan Publik), dan dalam penelitian ini mengacu pada penyataan Sunarjanto dan Tulasi (2013) yang menyatakan bahwa laporan keuangan yang diaudit oleh KAP big four dinilai lebih berkualitas apabila dibandingkan dengan KAP non big four, karena opini yang dihasilkan KAP big four akan lebih independen, sehingga dapat mengurangi agency risk, dan menurunkan default risk yang pada akhirnya akan meningkatkan peringkat obligasi perusahaan tersebut. Variable independen ini 
diukur menggunakan skala nominal Karena merupakan variable dummy. Pengukuran dilakukan dengan memberikan nilai 1 terhadap obligasi yang diaudit oleh big four, dan 0 terhadap obligasi yang diaudit oleh non big four, pengukuran ini mengacu pada penelitian Subariah (2014).

\section{Model Analisis Regresi}

Metode analisis yang digunakan untuk menguji hipotesis adalah analisis regresi berganda. Berikut adalah model empiris yang digunakan dalam penelitian :

$$
\begin{aligned}
\mathrm{RATING}= & \beta_{0}+\beta_{1} \mathrm{LAD}+\beta_{2} \mathrm{ROA}+\beta_{3} \mathrm{JAMIN}+\beta_{4} \mathrm{UMUR}+\beta_{5} \mathrm{REP}+\beta_{6} \mathrm{LEV}+ \\
& \beta_{7} \text { GROWTH }+\beta_{8} \mathrm{LnSIZE}+\varepsilon
\end{aligned}
$$

Keterangan:

- RATING: Peringkat Obligasi menggunakan kode 1-18 pada obligasi perusahaan.

- LAD : Saldo laba yang dihitung dari perbandingan anatara laba ditahan akhir periode pada total aset awal periode.

- ROA : Profitabilitas yang akan dihitung dengan perbandingan antara laba bersih setelah pajak pada total aset.

- JAMIN : Jaminan Obligasi, merupakan variabel dummy, jika perusahaan memberikan jaminan pada obligasi maka akan diberi nilai 1 , jika tidak memberikan jaminan pada obligasi maka akan diberi nilai 0 .

- UMUR : Umur Obligasi, diukur menggunakan peringkat, apabila 1 tahun akan diberikan kode 1 , dan seterusnya.

- REP : Reputasi Auditor, merupakan variabel dummy, jika obligasi di audit oleh big four akan diberi nilai 1, jikaobligasi diaudit oleh non big four akan diberi nilai 0 .

- LEVERAGE : Leverage yang akan dihitung dengan perbandingan total liabilitas pada total aset.

- GROWTH : Pertumbuhan Perusahaan yang akan dihitung dengan perbandingan antara jumlah saham beredar dikalikan dengan harga penutupan saham lalu hasilnya dibagikan pada total ekuitas.

- LnSIZE : Ukuran Perusahaan yang akan dihitung dengan logaritma natural dari total aset.

\section{HASIL DAN PEMBAHASAN}

\section{Statistik Deskriptif}

Tabel 2 menyajikan statistik deskriptif untuk semua variabel yang digunakan dalam penelitian. Dari tabel dapat dilihat bahwa peringkat obligasi yang diukur berdasarkan peringkat obligasi oleh PEFINDO mempunyai nilai minimum sebesar 1 dan nilai maksimum sebesar 18 . Rata-rata variabel peringkat obligasi dalam penelitian ini sebesar 13,5369 dengan standar deviasi sebesar 2,78830. Rata-rata peringkat obligasi (RATING) sebesar 13,5369 menunjukkan bahwa perusahaan BEI yang terdaftar pada PEFINDO tahun 2012-2016 memiliki rata-rata peringkat $A(A=13)$. Ini menunjukkan kinerja yang kuat dari rata-rata perusahaan yang terdaftar pada PEFINDO. Informasi ini bisa dijadikan acuan bagi investor yang hendak membeli obligasi dari perusahaan yang terdapat pada rentang waktu 2012-2016 di PEFINDO.

Variabel laba ditahan (LAD) yang dideflasi dengan total aset awal periode memiliki nilai minimum sebesar $-0,35$ dan nilai maksimum sebesar 0,54 . Rata-rata laba ditahan yaitu 0,1396 dengan standar deviasi sebesar 0,12273. Rata-rata 0,1396 menunjukkan bahwa perusahaan dalam sampel rata-rata memiliki jumlah laba ditahan mendekati nilai maksimal. 
Tabel 2.

Statistik Deskriptif

\begin{tabular}{|c|c|c|c|c|c|}
\hline & $\mathrm{N}$ & $\begin{array}{c}\text { Minimu } \\
\mathrm{m}\end{array}$ & $\begin{array}{c}\text { Maksimu } \\
\mathrm{m}\end{array}$ & Mean & $\begin{array}{c}\text { Std. } \\
\text { Dev. }\end{array}$ \\
\hline RATING & 203 & 1.00 & 18.00 & 13.536 & 2.788 \\
\hline LAD & 203 & -0.35 & 0.54 & 0.1396 & 0.12273 \\
\hline ROA & 203 & -10.75 & 0.80 & -0.005 & 0.76190 \\
\hline JAMIN & 203 & 0.00 & 1.00 & 0,5567 & 0.49801 \\
\hline UMUR & 203 & 1.00 & 30.00 & 5.6108 & 3.07034 \\
\hline REP & 203 & 0.00 & 1.00 & 0.5419 & 0.49948 \\
\hline LEV & 203 & 0.22 & 8.91 & 0.6810 & 0.60904 \\
\hline GROWTH & 203 & -0.96 & 10.02 & 1.9258 & 1.55911 \\
\hline SIZE & 203 & 26.61 & 34.58 & 29.991 & 1.51342 \\
& & & & 7 & \\
\hline
\end{tabular}

Profitabilitas (ROA) diukur dengan perbandingan laba bersih setelah pajak dengan total aset perusahaan. Dari hasil ditabel menunjukkan bahwa nilai minimum untuk ROA yaitu 10,75 dan nilai tertinggi yaitu 0,80 . Standar deviasi dari variabel ini adalah 0,76190 dan ratarata dari variabel ini adalah -0,0052. Rata-rata dari ROA perusahaan ini memiliki tanda negatif yang berarti secara rata-rata perusahaan sampel mengalami kerugian.

Tabel 3. Jaminan Obligasi

\begin{tabular}{|l|l|r|r|r|}
\hline \multicolumn{2}{|c|}{} & Frequency & \multicolumn{1}{c|}{ Percent } & \multicolumn{2}{c|}{$\begin{array}{c}\text { Cumulative } \\
\text { Percent }\end{array}$} \\
\hline \multirow{3}{*}{ Valid } &, 00 & 90 & 44,4 & 44,4 \\
\cline { 2 - 5 } & 1,00 & 113 & 55,6 & 100,0 \\
\cline { 2 - 5 } & Total & 203 & 100,0 & \\
\hline
\end{tabular}

Variabel independent jaminan obligasi (SEC) dalam penelitian ini diukur dengan menggunakan variabel dummy. Nilai 1 dikhususkan untuk perusahaan yang memberikan jaminan terhadap obligasi yang mereka terbitkan, lalu untuk nilai 0 dikhususkan untuk perusahaan yang tidak memberikan jaminan pada obligasi yang mereka terbitkan. Dari tabel 3 dapat diketahui bahwa perusahaan yang memberikan jaminan pada obligasinya yaitu sebanyak 55,7\% atau 113 perusahaan dari 203 perusahaan. Untuk perusahaan yang tidak memberikan jaminan pada obligasi yang mereka terbitkan adalah sebanyak $44,3 \%$ atau 90 perusahaan. Dapat kita tarik kesimpulan bahwa perusahaan pada sampel penelitian ini lebih banyak memberikan jaminan pada obligasi yang mereka terbitkan. Hasil perhitungan variabel ini menunjukkan nilai standar deviasi sebesar 0,4981.

Variabel selanjutnya adalah variabel maturity (UMUR) yang diukur dengan memberikan peringkat pada umur obligasi. Perhitungan variabel ini menghasilkan nilai minimum sebesar 1 dan nilai maksimum sebesar 30. Standar deviasi pada variabel ini 
adalah 3,07034 dan rata-rata dari variabel ini adalah 5,6. Secara rata-rata perusahaan menerbitkan obligasi dengan jarak waktu jatuh tempo 5 tahun atau diatas 5 tahun.

Tabel 4.

Reputasi Auditor

\begin{tabular}{|l|l|r|r|r|}
\hline \multicolumn{2}{|c|}{} & Frequency & \multicolumn{1}{c|}{ Percent } & \multicolumn{2}{c|}{$\begin{array}{c}\text { Cumulative } \\
\text { Percent }\end{array}$} \\
\hline \multirow{3}{*}{ Valid } &, 00 & 93 & 45,8 & 45,8 \\
\cline { 2 - 5 } & 1,00 & 110 & 54,2 & 100,0 \\
\cline { 2 - 5 } & Total & 203 & 100,0 & \\
\hline
\end{tabular}

Reputasi auditor merupakan variabel dummy yang memiliki nilai 1 jika perusahaan diaudit KAP big 4 dan 0 jika sebaliknya. Dari hasil tabel 4 pada penelitian ini menunjukkan bahwa jumlah perusahaan yang diaudit oleh KAP big 4 sebanyak $110(54,2 \%)$ lebih banyak dari perusahaan yang diaudit oleh KAP non big 4 sebanyak 93 (45,8\%). Dengan demikian rata-rata perusahaan pada sampel penelitian ini menggunakan KAP big 4. Hasil standar deviasi dari variabel ini adalah 0,49448.

Penelitian ini juga menggunakan variabel kontrol untuk mengendalikan pengaruh variabel lain terhadap peringkat obligasi. Variabel kontrol pertama adalah leverage (LEV) yang diukur dengan membagi total kewajiban perusahaan dengan total aset perusahaan. Perhitungan variabel ini memiliki nilai minimum sebesar 0,22 dan nilai maksimum sebesar 8,91. Standar deviasi variabel ini adalah 0,60904 dan rata-rata nya adalah 0,6810. Jumlah rata-rata sebesar 0,6810 menandakan bahwa setiap $\mathrm{Rp} 1$ aset digunakan untuk menjamin $\mathrm{Rp} 0,6810$ hutang ratarata perusahaan.

Varibel kontrol lainnya dalam penelitian ini adalah growth (GRO) yang hitung dengan membandingkan hasil dari perkalian antara harga penutupan saham dan jumlah saham yang beredar dengan total ekuitas perusahaan. Dari perhitungan variabel ini ditemukan nilai minimum sebesar $-0,96$ dan nilai maksimum sebesar 10,02. Standar deviasi dari variabel ini adalah 1,9258 dan rata-rata dari variabel ini adalah 1,55911. Dari hasil rata-rata tersebut menunjukkan bahwa perusahaan pada sampel penelitian memiliki rata-rata pertumbuhan sebesar 1,9258 kali dari total modal pada perkembangan perusahaan mereka setiap tahunnya, tentunya semakin besar perkembangan perusahaan maka semakin bagus juga kondisi modal perusahaan yang akan semakin besar dan digunakan dalam menghasilkan profit pada perusahaan mereka.

Variabel kontrol yang terakhir pada penelitian ini adalah ukuran perusahaan (SIZE) yang dihitung menggunakan logaritma natural pada total aset perusahaan. Nilai minimum sebesar 26,61 dan nilai maksimum sebesar 34,58. Standar deviasi dari variabel ini adalah 1,51342 dan rata-rata dari variabel ini adalah 29,9917. Hasil rata-rata dari variabel ini lebih condong terhadap nilai minimum yang berarti rata-rata ukuran perusahaan pada sampel penelitian ini memiliki ukuran perusahaan yang tidak cenderung maksimal berdasarkan perusahaan yang terdaftar pada PEFINDO. Ukuran perusahaan yang semakin besar akan dinilai semakin mampu untuk menanggung segala beban yang dating dikemudian hari.

\section{HASIL DAN PEMBAHASAN}

\section{Pengaruh Laba Ditahan Terhadap Peringkat Obligasi}

Hipotesis pertama pada penelitian ini adalah laba ditahan berpengaruh positif signifikan terhadap peringkat obligasi. Dari tabel 5 dapat dilihat bahwa saldo laba (LAD) menunjukkan koefisien sebesar 9,774 dan nilai sig/2 adalah sebesar 0,000 yang berarti kurang dari 0,01 . Hal ini berarti laba ditahan berpengaruh positif signifikan terhadap 
peringkat obligasi sehingga hipotesis pertama dalam penelitian ini diterima dan didukung secara statistik. Menurut Riyanto (2011) dalam Octavia (2014) mengatakan bahwa laba ditahan adalah salah satu sumber pendanaan yang sangat penting bagi perusahaan guna untuk membiayai kinerja perusahaan. Teori ini mendukung hasil hipotesis penelitian ini, karena jika semakin tinggi laba ditahan suatu perusahaan, maka perusahaan dapat dikatakan mampu untuk menanggung segala pendanaan untuk pembuktian kinerja mereka pada investor dan PEFINDO juga, hal ini tentunya sangat penting bagi perusahaan karena jika perusahaan masuk dalam status default akan membuat kinerja mereka buruk dimata investor dan PEFINDO, sehingga perusahaan harus memiliki cadangan laba ditahan yang kuat dan besar supaya selalu siap untuk menanggung segala pendanaan yang ada bagi kinerja mereka juga. Sehingga dapat ditarik kesimpulan bahwa laba ditahan berpengaruh secara positif pada peringkat obligasi. Dalam penelitian Octavia (2014) juga dikatakan bahwa makin besar laba ditahan dari sebuah perusahaan, maka makin baik pula peringkat obligasi perusahaan tersebut, sehingga probabilitas gagal bayarnya sangatlah rendah.

Hasil penelitian ini mendukung hasil penelitian Octavia (2014), Werastuti (2015), dan Estiyanti dan Yasa (2012) yang sudah meneliti tentang pengaruh laba ditahan terhadap peringkat obligasi yang menunjukkan bahwa laba ditahan berpengaruh positif terhadap peringkat obligasi.

Tabel 5.

Hasil Pengujian Hipotesis

\begin{tabular}{|l|r|r|r|r|r|r|}
\hline & \multicolumn{2}{|c|}{$\begin{array}{c}\text { Unstandardize } \\
\text { d Coefficients }\end{array}$} & $\mathrm{t}$ & $\begin{array}{r}\mathrm{Si} \\
\mathrm{g}\end{array}$ & $\begin{array}{r}\mathrm{Si} \\
\mathrm{g} \\
(\alpha / \\
2)\end{array}$ & Hasil \\
\cline { 2 - 7 } & $\mathrm{B}$ & $\mathrm{S} . \mathrm{E}$ & & & .000 & \\
\hline (Constant) & -21.56 & 2.749 & -7.844 & .000 & .000 & \\
\hline LAD & 9.774 & 1.051 & 9.304 & .000 & .000 & Diterima \\
\hline JAMIN & .169 & .241 & .701 & .484 & .242 & Ditolak \\
\hline ROA & 4.714 & .684 & 6.896 & .000 & .000 & Diterima \\
\hline UMUR & -.051 & .044 & -1.157 & .249 & .124 & Ditolak \\
\hline REP & .553 & .258 & 2.140 & .034 & .017 & Diterima \\
\hline GROWTH & .198 & .075 & 2.649 & .009 & .004 & Diterima \\
\hline LEV & 2.909 & .775 & 3.751 & .000 & .000 & Diterima \\
\hline SIZE & 1.041 & .094 & 11.06 & .000 & .000 & Diterima \\
\hline
\end{tabular}

\section{Pengaruh Profitabilitas Terhadap Peringkat Obligasi}

Hipotesis kedua pada penelitian ini adalah profitabilitas berpengaruh positif signifikan terhadap peringkat obligasi. Berdasarkan tabel 5, profitabilitas (ROA) menunjukkan koefisien sebesar 4,714 dan nilai sig/2 adalah sebesar 0,000 yang berarti kurang dari 0,05. Hal ini menunjukkan bahwa profitabilitas berpengaruh positif signifikan terhadap peringkat obligasi sehingga hipotesis ketiga dalam penelitian ini diterima dan didukung secara statistik.

Rasio ini menggunakan perbandingan laba bersih perusahaan dengan total aset perusahaan, yang mana bila perusahaan yang dapat menghasilkan profit besar dibandingkan asetnya, maka perusahaan tersebut memiliki kinerja yang baik. Rasio profitabilitas yang tinggi dapat menurunkan resiko insolvency yaitu resiko ketidakmampuan perusahaan dalam membayar hutang, selain itu dengan profitabilitas yang 
tinggi juga menandakan bahwa perusahaan mengindikasikan keuangan emiten yang baik (Baskoro \& Wahidahwati, 2014). Menurut Arifman (2013) ketika profit perusahaan tinggi maka peringkat obligasi juga akan tinggi, hal ini disebabkan karena semakin tinggi profit perusahaan maka kemampuan perusahaan untuk melunasi setiap beban perusahaan termasuk obligasi juga semakin tinggi, hal ini tentu akan sangat berpengaruh pada persepsi PEFINDO terhadap perusahaan yang dianggap siap akan kinerja yang bagus dalam menghasilkan profit guna mendanai obligasi yang sudah mereka terbitkan, sehingga secara tidak langsung berdasarkan penjelasan diatas, investor dapat menggunakan faktor ini guna mengukur tingkat kesiapan dan kinerja perusahaan dalam melunasi obligasi yang sudah mereka terbitkan.

Hasil ini didukung oleh penelitian Arifman (2013) dan Baskoro dan Wahidahwati (2014) dan Werastuti (2015) dan Supriyono et al. (2015) yang sudah melakukan penelitian ini dan menyatakan bahwa profitabilitas berpengaruh secara positif terhadap peringkat obligasi.

\section{Pengaruh Jaminan Obligasi Terhadap Peringkat Obligasi}

Hipotesis ketiga pada penelitian ini adalah jaminan obligasi berpengaruh positif terhadap peringkat obligasi. Berdasarkan tabel 5, jaminan obligasi menunjukkan (JAMIN) menunjukkan koefisien sebesar 0,169 dan nilai sig/2 sebesar 0,242 yang berarti lebih dari 0,05 . Hal ini berarti jaminan obligasi berpengaruh positif signifikan pada peringkat obligasi pada penelitian ini ditolak. Dari data statistik yang tersaji menunjukkan bahwa tidak ada beda antara perusahaan yang memiliki jaminan dengan perusahaan yang tidak memiliki jaminan pada obligasi yang mereka terbitkan. Menurut Baskoro dan Wahidahwati (2014) pengukuran PEFINDO tidak hanya sebatas pada ada tidaknya sebuah jaminan pada obligasi, namun lebih diutamakan pada besarnya nilai jaminan. Hal ini dikarenakan besarnya nilai jaminan akan lebih menjanjikan.

Penyebab lain ditolaknya variabel ini juga bisa disebabkan karena obligasi yang diberikan jaminan pasti akan menuntut jumlah hutang dari perusahaan yang lebih besar sehingga sebagian investor merasa memiliki resiko yang lebih tinggi jika jumlah uang yang perusahaan inginkan tinggi, maka sebagian investor memilih untuk tidak mau mengambil resiko pada kasus tersebut.

Hasil penelitian ini mendukung penelitian Almilia dan Devi (2007) dan Baskoro dan Wahidahwati (2014) yang menemukan bahwa jaminan obligasi tidak berpengaruh secara positif terhadap peringkat obligasi. Sedangkan penelitian ini tidak mendukung penelitian Azriya (2013), Magreta dan Nurmayanti (2009), dan Rusfika dan Wahidahwati (2015) yang menyatakan bahwa jaminan obligasi berpengaruh positif terhadap peringkat obligasi.

\section{Pengaruh Umur Obligasi Terhadap Peringkat Obligasi}

Hipotesis keempat pada penelitian ini adalah umur obligasi berpengaruh positif terhadap peringkat obligasi. Berdasarkan tabel 5, umur obligasi (UMUR) menunjukkan koefisien sebesar $-0,051$ dan nilai sig/2 sebesar 0,124 yang berarti lebih dari 0,05 . Hal ini berarti variabel umur obligasi tidak berpengaruh signifikan terhadap peringkat obligasi. Hipotesis penelitian ini ditolak. Dari data statistik yang tersaji menunjukkan bahwa perusahaan yang memiliki umur obligasi pendek belum tentu dianggap tidak beresiko dibandingkan dengan perusahaan yang memiliki umur obligasi yang panjang, hasil ini juga didukung oleh bukti anekdotal PT. Trikomsel Oke (TRIO) yang mengalami gagal bayar obligasi tahun 2015 padahal jika dilihat umur obligasi TRIO sendiri hanya berjangka 5 tahun, sehingga umur yang pendek belum tentu memiliki peringkat obligasi yang tinggi. Hal ini menunjukkan bahwa perusahaan yang memiliki umur obligasi pendek dinilai belum 
siap untuk melunasi hutang obligasi yang mendatang, sehingga perusahaan harus memasang jangka waktu obligasi dengan umur yang lebih panjang.

Perusahaan yang menerbitkan obligasi dengan umur yang lebih panjang seharusnya dianggap lebih siap dari pada perusahaan yang menerbitkan obligasi dengan umur lebih pendek, karena mereka memiliki kesempatan untuk meningkatkan kinerja, menambahkan profit mereka dengan waktu yang lebih lama sehingga dinilai lebih siap jika dibandingkan dengan perusahaan yang umur obligasinya cenderung pendek, hal ini akan menyebabkan kurangnya persiapan perusahaan tersebut mendanai obligasi yang sudah mereka terbitkan menjelang tanggal jatuh tempo, terlebih dalam penelitian ini hampir seluruh perusahaan memiliki umur obligasi 5 tahun bahkan diatasnya, hal ini juga menunjukkan bahwa umur obligasi pendek tidak terlalu diperhitungkan dalam pemeringkatan obligasi (Estiyanti \& Yasa, 2012)

Hasil penelitian ini didukung oleh Estiyanti dan Yasa (2012), dan Almilia dan Devi (2007) yang menyatakan bahwa umur obligasi tidak berpengaruh terhadap peringkat obligasi. Sedangkan peneletian ini tidak mendukung penelitian Andry (2005), Supriyono et al. (2015), Veronica (2013), dan Widastuti dan Rahyuda (2016) yang menyatakan bahwa umur obligasi berpengaruh secara negatif terhadap peringkat obligasi.

\section{Pengaruh Reputasi Auditor Terhadap Peringkat Obligasi}

Hipotesis kelima pada penelitian ini adalah reputasi auditor berpengaruh positif signifikan terhadap peringkat obligasi. Berdasarkan tabel 5, reputasi auditor (REP) menunjukkan koefisien sebesar 0,553 dan nilai sig/2 adalah sebesar 0,017 yang berarti kurang dari 0,05 . Hal ini berarti reputasi auditor berpengaruh positif signifikan terhadap peringkat obligasi sehingga hipotesis kelima dalam penelitian ini diterima dan didukung secara statistik.

Salah satu cara untuk mengurangi asimetri informasi yaitu perusahaan harus memberikan sinyal kepada pihak eksternal berupa kualitas informasi yang diungkapkan oleh perusahaan pada laporan keuangan. Informasi yang dimaksud merupakan opini dari auditor yang dianggap sangat penting bagi para pembaca laporan keuangan terutama para investor karena laporan auditor memberikan ilustrasi mengenai kondisi suatu perusahaan (Widowati et al.,2013). Reputasi auditor yang baik disini yang dimaksudkan adalah auditor big 4. Allen (1994) dalam Andry (2005) juga memberikan alasan mengapa auditor big four lebih baik dibanding auditor non big four karena auditor big four dapat memberikan prediksi keputusan peringkat obligasi terhadap perusahaan dan pemerintah daerah. Selain itu Chrisnoventie \& Raharja (2012) mengatakan bahwa KAP big four berkaitan dengan teori deep pocket dimana KAP big four memiliki kemakmuran yang lebih banyak dalam risiko, khususnya saat mereka menangani klien dengan risiko litigasi yang besar dari pihak eksternal yang merasa dirugikan dari hasil audit yang keluar, mengingat hal tersebut sebagai KAP big four benar-benar harus menjaga kualitasnya karena bisa saja pihak eksternal memang memanfaatkan keuntungan tersebut dan tentunya pihak eksternal tidak akan memerkarakan kepada non big four karena dianggap tidak memiliki kemakmuran seperti yang dimaksud.

Hasil dari penelitian ini didukung oleh penelitian Subariah (2014) dan Widowati et al. (2013) dan Andry (2005) yang menyatakan bahwa reputasi auditor berpengaruh positif terhadap peringkat obligasi.

\section{Variabel Kontrol}

Penelitian ini memakai 3 variabel kontrol diantaranya leverage, growth, ukuran perusahaan. Nilai signifikansi leverage (LEV)pada penelitian ini adalah 0,000 kurang dari 0,05 dimana hipotesis bahwa leverage berpengaruh secara negatif terhadap peringkat 
obligasi yang diterbitkan perusahaan diterima. Jika hasil perhitungan rasio leverage cukup tinggi, maka dapat dipastikan bahwa sebagian dari total aset didanai oleh utang, hal ini tentunya akan menunjukan kinerja yang semakin buruk apabila jumlah total hutang lebih besar dari pada total aset, jadi semakin rendah leverage maka semakin tinggi peringkat obligasi yang akan diberikan oleh PEFINDO (Adrian, 2011). Hasil ini mendukung penelitian Supriyono et al. (2015) yang menyatakan bahwa leverage berpengaruh negative terhadap peringkat obligasi.

Variabel kontrol kedua adalah growth (GROWTH) yaitu pertumbuhan usaha yang diukur dengan market value to book value. Berdasarkan hasil penelitian ini, variabel growth memiliki nilai signifikansi sebesar 0,004 < 0,05 dimana hipotesis bahwa growth berpengaruh secara positif terhadap peringkat obligasi diterima. Hipotesis diatas juga didukung oleh Pottier dan Sommer (1999) dalam Almilia dan Devi (2007), dia mengatakan bahwa growth dari bisnis perusahaan yang sangat kuat berhubungan positif dengan hasil peringkat yang nantinya akan diberikan agen pemeringkat, karena pertumbuhan perusahaan menunjukkan peningkatan kinerja dari arus kas masa datang serta juga meningkatkan nilai ekonomi perusahaan. Hasil ini didukung oleh Almilia dan Devi (2007) yang menyatakan bahwa growth berpengaruh secara positif terhadap peringkat obligasi.

Variabel kontrol terakhir dalam penelitian ini adalah ukuran perusahaan (SIZE) yang diukur menggunakan logaritma natural dari total aset perusahaan. Berdasarkan hasil penelitian, didapatkan hasil nilai signifikansi sebesar 0,000 kurang dari 0,05 dimana hipotesis bahwa ukuran perusahaan berpengaruh secara positif terhadap peringkat obligasi diterima. Menurut Suryani (2007) dalam Alfiani (2013) ukuran perusahaan menggambarkan besar kecilnya suatu perusahaan yang ditujukkan oleh total aset, jumlah penjualan, rata-rata total penjualan, dan rata- rata aktiva. Dari hasil penelitian diatas membuktikan bahwa perusahaan yang besar akan mendapatkan peringkat yang tinggi pula dari PEFINDO. Hasil ini didukung oleh Alfiani (2013) yang menyatakan bahwa ukuran perusahaan berpengaruh secara positif terhadap peringkat obligasi.

\section{KESIMPULAN DAN SARAN}

\section{Kesimpulan}

Penelitian ini merupakan penelitain sekunder empiris yang bermaksud untuk menguji pengaruh laba ditahan, jaminan obligasi, profitabilitas, umur obligasi, reputasi auditor terhadap peringkat obligasi yang diberikan oleh PEFINDO.

Berdasarkan penelitian ini, terdapat beberapa kesimpulan yang ingin disampaikan oleh penulis sebagai berikut :

1. Variabel laba ditahan berpengaruh positif terhadap peringkat obligasi diterima dalam penelitian ini dengan nilai sig $0,000<0,05$. Hasil penelitian ini mendukung hasil penelitian Octavia (2014), Werastuti (2015), dan Estiyanti dan Yasa (2012) yang sudah meneliti tentang pengaruh laba ditahan terhadap peringkat obligasi yang menunjukkan bahwa laba ditahan berpengaruh positif terhadap peringkat obligasi.

2. Variabel profitabilitas berpengaruh positif terhadap peringkat obligasi diterima dalam penelitian ini dengan nilai sig 0,000 $<0,05$. Hasil ini didukung oleh penelitian Arifman (2013) dan Baskoro dan Wahidahwati (2014) dan Werastuti (2015) dan Supriyono et al. (2015) yang sudah melakukan penelitian ini dan menyatakan bahwa profitabilitas berpengaruh secara positif terhadap peringkat obligasi.

3. Variabel jaminan obligasi berpengaruh positif terhadap peringkat obligasi ditolak dalam penelitian ini dengan nilai sig 0,242 $><0,05$. Almilia dan Devi (2007) dan Baskoro dan 
Wahidahwati (2014) mendukung hasil ini. Sedangkan Azriya (2013), Magreta dan Nurmayanti (2009), dan Rusfika dan Wahidahwati (2015) tidak mendukung hasil ini.

4. Variabel umur obligasi berpengaruh negatif terhadap peringkat obligasi ditolak pada penelitian ini dengan nilai sig 0,124 >0,05. Estiyanti dan Yasa (2012), dan Almilia dan Devi (2007) mendukung hasil ini, sedangkan Andry (2005), Supriyono et al. (2015), Veronica (2013), dan Widastuti dan Rahyuda (2016) tidak mendukung hasil ini.

5. Variabel reputasi auditor berpengaruh positif terhadap peringkat obligasi diterima dalam penelitian ini dengan nilai sig 0,017 < 0,05. Hasil dari penelitian ini didukung oleh penelitian Subariah (2014) dan Widowati et al. (2013) dan Andry (2005) yang menyatakan bahwa reputasi auditor berpengaruh positif terhadap peringkat obligasi.

6. Variabel kontrol leverage berpengaruh terhadap peringkat obligasi pada penelitian ini diterima dengan nilai sig $0,000<0,05$. Hasil ini mendukung penelitian Supriyono et al. (2015) yang menyatakan bahwa leverage berpengaruh terhadap peringkat obligasi.

7. Variabel kontrol growth berpengaruh terhadap peringkat obligasi pada penelitian ini diterima dengan nilai sig 0,004 < 0,05. Hasil ini didukung oleh Almilia dan Devi (2007) yang menyatakan bahwa growth berpengaruh terhadap peringkat obligasi.

8. Variabel kontrol ukuran perusahaan berpengaruh terhadap peringkat obligasi pada penelitian ini diterima dengan nilai sig 0,000<0,05. Hasil ini didukung oleh Alfiani (2013) yang menyatakan bahwa ukuran perusahaan berpengaruh terhadap peringkat obligasi.

\section{Keterbatasan dan Saran}

Keterbatasan yang ditemukan pada penelitian ini adalah sebagai berikut: 1) Peneliti sulit dalam menentukan obligasi yang dijaminkan dengan obligasi tanpa jaminan. Hal ini disebabkan karena beberapa laporan tidak menyertakan keterangan jaminan. 2) Pengukuran jaminan dengan variabel dummy dirasa kurang memberikan hasil yang kritis karena beberapa perusahaan memberikan jaminan dengan nilai yang lebih tinggi dari perusahaan lainnya.

Penelitian selanjutnya dapat menambahkan faktor keuangan seperti rasio likuiditas, solvabilitas supaya hasil yang ada akan lebih kritis dengan banyak faktor dan akan memberikan informasi yang lebih komprehensif terhadap masyarakat. Untuk penelitian selanjutnya dalam mengukur jaminan sebaiknya digunakan pengukuran peringkat berdasarkan jumlah nominal jaminan yang diberikan oleh perusahaan, sehingga akan memberikan hasil yang lebih kritis dalam pengukuran peringkat obligasi ini.

\section{DAFTAR PUSTAKA}

Alfiani, A. P. 2013. Pengaruh Rasio Solvabilitas, Rasio Aktivitas, Rasio Likuiditas Dan Ukuran Perusahaan Terhadap Peringkat Obligasi Perusahaan (Perusahaan Non Keuangan yang Terdaftar di BEI Tahun 2008-2011). Jurnal Akuntansi, 1-27.

Almilia, L. S., dan V. Devi. 2007. Faktor-Faktor yang Mempengaruhi Prediksi Peringkat Obligasi pada Perusahaan Manufaktur yang Terdaftar Di Bursa Efek Jakarta. Proceeding Seminar Nasional Manajemen smart, (November), 1-23.

Andry, W. 2005. Analisis faktor-faktor yang mempengaruhi prediksi peringkat obligasi. Buletin Ekonomi Moneter Dan Perbankan, 2(1), 243-262.

Arifman, Y. 2013. Pengaruh Likuiditas, Profitabilitas dan Leverage terhadap Peringkat Obligasi Perusahaan (Studi Empiris pada Perusahaan yang Terdaftar di Bursa Efek Indonesia). 
Azriya, N. 2013. Analisis Pengaruh Faktor Akuntansi dan Non Akuntansi terhadap Peringkat Obligasi.

Baskoro, A. F., dan Wahidahwati. 2014. Pengaruh Faktor Keuangan Dan Non Keuangan Pada Peringkat Obligasi Di Bursa Efek Indonesia. Jurnal Ilmu \& Riset Akuntansi Vol. 3 No. 6 (2014), 3(6), 1-23.

Chrisnoventie, D. dan S. Raharja. 2012. Pengaruh Ukuran Kap Dan Spesialisasi Industri Kap Terhadap Kualitas Audit: Tingkat Risiko Litigasi, 1(2005), 1-15.

Estiyanti, N. M., dan G. W. Yasa. 2012. Pengaruh Faktor Keuangan Dan Non Keuangan pada Peringkat Obligasi di Bursa Efek Indonesia. Jurnal Universitas Udayana, 1-23.

Ghozali, I. 2016. Aplikasi analisis multivariete dengan program IBM SPSS 23 (8th ed.). Semarang: Badan Penerbit Universitas Diponegoro.

Gunawan, H. 2015. Trikomsel gagal bayar bunga obligasi.

Gunawijaya, I. N. A. 2015. Pengaruh Karakteristik Komiter Audit, Independensi Dewan Komisaris, Reputasi Auditor terhadap Financial Distress, XIV(27), 111-130.

Magreta, dan P. Nurmayanti. 2009. Faktor-faktor yang Mempengaruhi Prediksi Peringkat Obligasi Ditinjau dari Faktor Akuntansi dan Non Akuntansi. Jurnal Bisnis Dan Akuntansi, 11(3), 143-154.

Natasia, W., dan Wahidahwati. 2015. Faktor-faktor yang mempengaruhi kebijakan hutang perusahaan manufaktur. Jurnal Ilmu \& Riset Akuntansi, 4(3).

Octavia, R. 2014. Pengaruh pertumbuhan perusahaan, saldo laba, dan aliran kas operasi terhadap peringkat obligasi (studi empiris pada Perusahaan yang terdaftar di BEI periode 2009-2012).

Sejati, G. P. 2010. Analisis Faktor Akuntansi dan Non Akuntansi dalam Memprediksi Peringkat Obligasi Perusahaan Manufaktur. Jurnal Ilmu Administrasi Dan Organisasi, Bisnis \& Birokrasi, 17(1), 70-78.

Subariah. 2014. Analisis Faktor-Faktor yang Mempengaruhi Prediksi Peringkat Obligasi pada Perusahaan Keuangan yang Terdaftar di Bursa Efek Indonesia Periode 2012-2014. Universitas Maritim Raja Ali Haji, 1-27.

Sugiarto, R. 2012. Peran Faktor Internal Dan Eksternal Terhadap Audit Delay. Berkala Ilmiah Mahasiswa Akuntansi Fakultas Bisnis Unika Widya Mandala, 1(2).

Sulistyastuti, D. R. 2002. Saham \& Obligasi Ringkasan Teori dan Soal Jawab (1st ed.). Yogyakarta: Universitas Atma Jaya Yogyakarta.

Sunarjanto, N. A., dan D. Tulasi. 2013. Kemampuan Rasio Keuangan Dan Corporate Governance Memprediksi Peringkat Obligasi Pada Perusahaan Consumer Goods. Jurnal Keuangan Dan Perbankan, 17(2), 230-242. 
Supriyono, E., R. Yaya, dan K. O. Tensia. 2015. variabel-variabel yang dapat memengaruhi peringkat obligasi (Studi Kasus Perusahaan Non Keuangan dan Non Jasa yang Terdaftar di Bursa Efek Indonesia), 6(2).

Veronica, A. 2013. Faktor-Faktor yang Mempengaruhi Peringkat Obligasi pada Perusahaan Manufaktur. Jurnal Manajemen Dan Bisnis Sriwijaya, 13, 274-282.

Widiastuti, N. P. T., dan H. Rahyuda. 2016. Pengaruh Pertumbuhan Perusahaan , Rasio Likuiditas , FakultasiEkonomi dan Bisnis Universitas Udayana ( Unud ), Bali , Indonesia Saat ini banyak perusahaan menerbitkan obligasi selain menerbitkan saham sebagai sumber pendanaan perusahaan . Kondisi tersebut, 5(11), 6964-6993.

Widowati, D., Y. Nugrahanti, dan A. B. Kristanto. 2013. Analisis Faktor Keuangan dan Non Keuangan yang Berpengaruh pada Prediksi Peringkat Obligasi di Indonesia (Studi pada Perusahaan Non Keuangan yang Terdaftar di BEI dan di Daftar Peringkat PT Pefindo 2009-2011). Jurnal Manajemen Maranatha, 13(1), 35-54.

Wijayanti, I., dan M. P. Priyadi. 2014. Faktor-Faktor yang Mempengaruhi Peringkat Obligasi. Jurnal Ilmu \& Riset Akuntansi Vol. 3 No. 3 (2014). 